Semina $\square \quad \mathrm{Nr} 13$

Scientiarum 2014

s. $177-183$

DOI: http://dx.doi.org/10.15633/ss.691

\title{
Neuronaukowe badania
}

\section{sióstr zakonnych i krytyka materializmu}

Mario Beauregard, Denyse O’Leary, Duchowy mózg.

Neuronaukowa argumentacja za istnieniem duszy, tłum.

Zbigniew Kasprzyk, Wydawnictwo WAM, Kraków 2011, ss. 483

Książka Duchowy mózg. Neuronaukowa argumentacja za istnieniem duszy, której autorami sa Mario Beauregard i Denyse O'Leary to prezentacja badań przeprowadzonych na grupie zakonnic ze zgromadzenia kontemplacyjnego, których celem było przybliżenie przebiegu domniemanych DRDM, czyli doświadczeń religijnych, duchowych i/lub mistycznych. Badania te, sfinansowane przez Fundację Templetona, wykonał na Uniwersytecie w Montrealu neuronaukowiec dr Mario Beauregard ${ }^{1}$ wraz ze swoim doktorantem Vincentem Paquette'em. Należy podkreślić, że Beauregard jest głównym autorem tejże książki, zaś autorstwo O’Leary (dziennikarki piszacej o związkach nauki, religii i wiary) ma raczej charakter pomocniczy. Przedstawienia domaga się również zawarta tam krytyka podejścia materialistycznego w neuronauce, która stanowi wprowadzenie do wspomnianych badań, a zarazem zajmuje większą część książki. We wstępie do niej czytelnik może bowiem przeczytać: „Książka ta - odchodząc od ogólnej tendencji w popularnonaukowych publikacjach na temat neuronauki - kwestionuje

1 Dr Mario Beauregard - neuronaukowiec związany obecnie z Uniwersytetem w Arizonie, jest autorem ponad setki publikacji z zakresu neuronauki, psychologii i psychiatrii; oprócz współautorstwa Duchowego mózgu napisał także kolejną książkę: Brain Wars. The Scientific Battle Over the Existence of the Mind and the Proof That Will Change the Way We Live Our Lives, New York 2012. 
zasadność materialistycznych koncepcji. Co więcej - dostarcza dowodów na ich fałszywość" ${ }^{2}$. Cytat ten ujawnia niematerialistyczne poglądy autorów, którzy starają się w swej książce wszelkimi sposobami przekonać czytelnika, iż poglądy materialistyczne są chybione. W tym celu przeprowadzają na kartach Duchowego mózgu specjalną krytykę wybranych teorii, które też jako pierwsze zostaną teraz pokrótce przytoczone.

$\mathrm{Na}$ początku autorzy poddaja krytyce kilka popularnych teorii dotyczących przeżyć duchowych, wspierających światopogląd ateistyczny. Jedna z nich jest teoria wysunięta przez Matthew Alpera, który zakłada, że ewolucja zaprogramowała ludzi w taki sposób, aby wierzyli w Boga (tak pojęta duchowość byłaby genetycznie dziedziczoną cechą gatunku). Innymi teoriami są na przykład: teoria „Bożego genu” zaproponowana przez biologa Deana Hamera, który uważa, że człowiek jest wiązką reakcji chemicznych kierowana przez DNA, oraz teoria „modułu Boga” wysunięta przez Jeffreya Savera i Johna Rabina, a głosząca, że w mózgu człowieka istnieje pewien moduł, który tłumaczy religijne wizje i uczucia ekstazy ${ }^{3}$. Następnie autorzy prowadzą rozważania na temat wpływu padaczki skroniowej na DRDM, a także omawiają zastosowanie skonstruowanego przez Michaela Persingera tzw. Bożego kasku rzekomo wywołującego DRDM poprzez elektromagnetyczna stymulację płatów skroniowych ${ }^{4}$. W końcu czytelnik spotka się również z próba odpowiedzi na jedno z podstawowych pytań filozofii umysłu, a mianowicie na pytanie: „Czym jest ludzki umysł?”. Autorzy przytaczają dane, które ich zdaniem świadczą o tym, że mózg i umysł nie sa ze sobą tożsame ${ }^{5}$. Starają się też dowieść, że umysł oddziałuje na mózg jako przyczyna o niematerialnym charakterze. Podają hipotezę dotyczącą interakcji pomiędzy mózgiem i umysłem, popierając ją wynikami badań naukowych, które mają ponoć potwierdzać wy-

2 M. Beauregard, D. O'Leary, Duchowy mózg. Neuronaukowa argumentacja za istnieniem duszy, Kraków 2011, s. 13.

3 Por. tamże, s. 79-132.

4 Por. tamże, s. 133-166.

5 Por. tamże, s. 167-200. 
stępowanie doświadczeń z pogranicza śmierci (śmierć kliniczna). Co więcej, chcą tą drogą uprawdopodobnić przypuszczenie, jakoby mistycy znajdujący się w stanie ekstazy mieli naprawdę doświadczać czegoś ponadnaturalnego ${ }^{6}$.

W dalszej części książki autorzy zastanawiają się nad tym, kto ma doświadczenia mistyczne, oraz co je wywołuje. Przyglądają się ciekawej pracy Alistera Hardy'ego, zoologa, który w roku 1969 założył Religious Experience Research Unit (jednostka do badań nad doświadczeniami religijnymi) w Manchester College na Uniwersytecie w Oxfordzie. Jednostka ta zajmowała się gromadzeniem opisów DRDM oraz badaniem ich natury i funkcji - owocem tego było opublikowanie książki The Spiritual Nature of Man ${ }^{7}$, która zawierała przeglądową analizę ponad trzech tysięcy świadectw osobistych DRDM. Praca ta podaje, że czynnikami najczęściej wywołujacymi DRDM były: modlitwa, medytacja, piękno natury, a także udział w nabożeństwach religijnych. Autorzy korzystaja z wyników tych badań, aby podkreślić rolę, jaką w mistyce chrześcijańskiej odgrywała modlitwa kontemplacyjna ${ }^{8}$. Ostatnim omawianym zagadnieniem, poprzedzajacym bezpośrednio przedstawienie badań sióstr zakonnych, jest wpływ DRDM na życie danej jednostki. Jego streszczeniem jest wniosek, iż efekt tych doświadczeń ma zazwyczaj pozytywny charakter dla jednostki - prowadzą one najczęściej do poważnych życiowych zmian: w obieraniu życiowego celu, w sposobie okazywania uczuć, a nawet mogą powodować poprawę stanu zdrowia9

Przechodząc teraz do głównego tematu książki, warto zaznaczyć, że rozpoczęcie badań nad doświadczeniami duchowymi było dla dr Beauregarda i jego doktoranta Paquette'a związane z niemałymi trudnościami. Musieli oni bowiem znaleźć odpowiednie osoby, które wyraziłyby zgodę na ich przeprowadzenie (pomocną w tym okazała się deklaracja naukowców, że celem ich badań nie jest chęć

\footnotetext{
6 Por. tamże, s. 201-282.

7 Zob. A. Hardy, The Spiritual Nature of Man, Clarendon, Oxford 1979.

8 Por. M. Beauregard, D. O'Leary, Duchowy mózg. Neuronaukowa argumentacja za istnieniem duszy, dz. cyt., s. 283-352.

9 Por. tamże, s. 353-390.
} 
wykazania, że DRDM nie istnieja, ale próba zidentyfikowania neuronalnych odpowiedników domniemanych przeżyć). W końcu badacze przekonali grupę piętnastu karmelitanek z Quebecu w wieku od 22 do 64 lat (średni wiek - 50 lat), które w swym życiu zakonnym spędzają wiele godzin na modlitwie. Wszystkie z nich przyznały, że przynajmniej raz przeżyły intensywne doświadczenie zjednoczenia mistycznego. Badania zostały przeprowadzone w ośrodku badawczym Instytutu Geriatrii Uniwersytetu w Montrealu oraz w jego Centrum Badań Neuropsychologicznych i Poznawczych, za pomoca technik neuroobrazowania, które zostały uzupełnione wywiadami z badanymi zakonnicami. Badacze poprosili zakonnice, aby przywołały wspomnienie swego najbardziej intensywnego doświadczenia mistycznego i przeżyły je ponownie, w trakcie czego przeprowadzili dwa typy badań. Pierwsze badanie polegało na przeprowadzeniu neuroobrazowania mózgów zakonnic technika fMRI (funkcjonalnego rezonansu magnetycznego), w celu ustalenia, które obszary sa aktywne podczas doświadczenia mistycznego. Oprócz skaningu $w$ warunkach stanu mistycznego, zakonnice poddano skaningowi w warunkach kontrolnych (podczas ponownego przeżycia najbardziej intensywnego stanu zjednoczenia z innym człowiekiem, jaki kiedykolwiek odczuwały), a także w warunkach poczatkowych (w normalnym stanie świadomości) ${ }^{10}$. Drugie badanie sprowadzało się do rejestracji zapisu fal mózgowych z wykorzystaniem techniki QEEG (elektroencefalografii ilościowej). Podczas badania wykorzystano te same trzy rodzaje warunków eksperymentalnych. W zaciemnionym i dźwiękoszczelnym pomieszczeniu, w którym odbył się eksperyment, dokonano pomiaru elektrycznych potencjałów na powierzchni czaszki, odzwierciedlających układ fal mózgowych. Badania technikami fMRI i QEEG zostały dopełnione przez sporządzone wywiady, podczas których zakonnice były proszone o opisanie i ocenę własnych przeżyć. Wszystkie z nich przyznały, że podczas badań doświadczyły stanów mistycznych, a opisywały je w kategoriach bezwarunkowej miłości, a także odczucia

10 Por. tamże, s. 402-410. 
pełni i pokoju ${ }^{11}$. Po zakończeniu badań Beauregard i O’Leary streścili ich wyniki w następujący sposób:

Pierwsze badanie wykazało przede wszystkim, że w doświadczeniu mistycznym bierze udział wiele obszarów, a nie tylko płaty skroniowe. [...] Nasze odkrycia dowodzą że nie istnieje pojedyncze „Boże miejsce” w płatach skroniowych mózgu człowieka. Obiektywnie i subiektywnie uzyskane dane sugerują raczej, że DRDM mają złożony i wielowymiarowy charakter, a w ich przeżywaniu pośredniczą obszary mózgowe, które w normalnych warunkach odpowiadają za percepcję, procesy poznawcze, emocje, reprezentację ciała oraz samoświadomość. [...] Jeśli chodzi o dane uzyskane metodą QEEG w warunkach mistycznych, w porównaniu z warunkami początkowymi, zaobserwowano znaczną wzmożoną emisję fal theta. [...] Należy zwrócić uwagę, że kiedy zakonnice przywoływały autobiograficzne wspomnienia, schemat aktywności mózgu był inny niż w momencie osiaggania stanu mistycznego. Wiemy więc na pewno, że stan mistyczny jest czymś innym niż stan emocjonalny ${ }^{12}$.

Autorzy komentują jeszcze owe badania poprzez odpowiedź na pytanie: „Czy nasze odkrycia dowodza, że mistycy wchodzą w kontakt z jakáś siłą znajdująca się poza nimi? Nie, tego nie można udowodnić ani zanegować"13. Zaraz też dodaja, że to, co ich zdaniem umożliwiają tego typu badania, to wskazanie schematów odpowiedzialnych za doświadczenia duchowe oraz wykluczenie prostych wyjaśnień - gdyż przeczy im złożony schemat aktywności mózgu zaobserwowany u badanych zakonnic ${ }^{14}$. Książka kończy się nakreśleniem nowego naukowego układu odniesienia, przychylnego wobec możliwości występowania DRDM. Układ ten miałby być niezbędny dla postawienia dalszego kroku na drodze odkrywania tajemnic umysłu ${ }^{15}$.

\footnotetext{
11 Por. tamże, s. 411-418.

12 Tamże, s. 416-420.

13 Tamże, s. 421.

14 Por. tamże.

15 Por. tamże, s. 447.
} 
Na koniec przyszedł czas, by odnieść się krytycznie do książki i spróbować sformułować jakąśs opinię na jej temat. Tak więc, wydaje mi się dość prawdopodobne, że jej czytelnik będzie miał co do niej mieszane uczucia. Na pierwszy rzut oka książka ta, ze względu choćby na użyty w niej barwny język (bogaty w przykłady, anegdoty), wydaje się ciekawa (już sam pomysł tego typu badań jest intrygujący), jednak uważam, że wrażenie to może zostać zakłócone przez rodząca się wątpliwość: czy aby nie zastosowano tu jakiegoś pochopnego uproszczenia? Przede wszystkim chcę zwrócić uwagę na zasadniczą niejasność: z jednej strony, jak zostało już pokazane, autorzy stanowczo odrzucają możliwość naukowego dowodzenia istnienia zewnętrznej rzeczywistości duchowej, ale z drugiej strony wielokrotnie stwarzają atmosferę, jakoby właśnie istnienia takiej rzeczywistości dowodzili, i to w sposób poparty powagą naukowa - wystarczy zacytować fragment książki, aby to zobrazować: „Udowodnimy, że kiedy dzięki duchowym doświadczeniom dokonuje się w życiu człowieka istotna przemiana, najbardziej rozsądnym (a jednocześnie uwzględniającym wszystkie dostępne dowody) wyjaśnieniem tego zjawiska jest stwierdzenie, że ludzie przeżywający podobne doświadczenia naprawdę nawiązują kontakt z zewnętrzną rzeczywistością"16. I tu pojawia się pytanie: czyżby więc pod szyldem takiego „rozsądnego uprawdopodabniania” autorzy chcieli przemycić dowód? Jeżeli tak, to uważam, że dowód ten ma bardziej charakter „pobożnego życzenia” aniżeli naukowego odkrycia. Aby nieco złagodzić moją wypowiedź, chcę zwrócić uwagę na fakt, że w dobie słabej „kondycji duchowej” sporej części przedstawicieli świata nauki ta oryginalna odwaga autorów do lepiej czy gorzej opracowanego głoszenia niewystarczalności teorii materialistycznych mimo wszystko zasługuje na uwagę - może bowiem komuś otworzyć bramę do jakichś ,ignorowanych możliwości”. Prócz tego warto pamiętać, że odkrywanie tajemnic umysłu należy dziś do najtrudniejszych zadań, wymagających interdyscyplinarnego zaangażowania, to zaś sprawia trudność utrzymania swych dociekań

16 Tamże, s. 18-19. 
w ramach zdrowego naukowego podejścia (osobnym problemem jest ustalenie, na czym ma ono polegać) - stąd też nieraz podobne zarzuty można by kierować pod adresem tych, którzy zdają się dowodzić materializmu. Sądzę zatem, że najmocniejszą stroną książki jest prezentacja wyników badań, zaś dołączony do tego komentarz autorów jest sprawą drugorzędna - czytelnik sam rozsądzi, na ile badania te są wiarygodne i go przekonuja.

Amadeusz Pala 